\title{
PAX3/FOXO4 Fusion Protein
}

National Cancer Institute

\section{Source}

National Cancer Institute. PAX3/FOXO4 Fusion Protein. NCI Thesaurus. Code C101068.

A fusion protein encoded by the PAX3/FOXO4 fusion gene. This protein is comprised of the $\mathrm{N}$-terminal DNA binding domain of paired box protein Pax-3 and the C-terminal transactivation domain of forkhead box protein 04. 